\title{
Introduction: The Posterizing Impulse in Philosophy of History
}

\author{
Herman Paul| ORCID: 0000-0002-9365-6329 \\ Professor of the History of Humanities, Institute for History, \\ Faculty of Humanities, Leiden University, Leiden, The Netherlands \\ h.j.paul@hum.leidenuniv.nl \\ Larissa Schulte Nordholt | ORCID: 0000-0002-0318-1324 \\ Lecturer, Institute for History, Faculty of Humanities, Leiden University, \\ Leiden, The Netherlands \\ l.r.c.schulte.nordholt@hum.leidenuniv.nl
}

Why do philosophy of history books so easily end up on the scrap heap of history ${ }^{1}$ Why does nobody anymore read Raymond Martin's The Past Within Us (1989), despite this little book offering a stimulating correction to the tendency, not uncommon in the field, of privileging conceptual reflection over empirical analysis? Why is Henri-Irénée Marrou's "treatise on the virtues of the historian," published in 1954 as De la connaissance historique, almost entirely forgotten, notwithstanding the "virtue turn" that is manifesting itself throughout the humanities and social sciences? Or why is Hanno Kesting's Geschichtsphilosophie und Weltbürgerkrieg (1959) collecting dust on library shelves, despite the fact that its analysis of historical narratives underpinning the Cold War, the project of European integration, and Third World development policies aligns well with a currently thriving type of intellectual history?

It is hard to generalize about a field as heterogenous as the philosophy of history. One thing, however, is certain: like many other humanities scholars, philosophers of history often feel more inclined to dissociate themselves from

1 We would like to thank the authors of this theme issue, most of whom composed their essays in the midst of a global pandemic. We are indebted to the eighteen anonymous reviewers who took the trouble to provide sometimes extensive comments and to Niklas Pietilä, Teemu Kontor, Jenni Hautamäki, Petra Aho, Anu Hannula, Atte Rautanen, and Hanna Ventomäki at the University of Oulu for copy-editing most of the articles in this issue. Also, we would like to thank Caroline Schep for standardizing all the footnotes and the Dutch Research Council (NWO) for providing generous research funding. 
predecessors in the field than to acknowledge how much they build on their work. At a time when intellectual "turns" seem to succeed each other ever more rapidly, philosophers of history, too, find it difficult to suppress what Paul C. Taylor calls a "posterizing impulse" - a desire to position themselves "beyond" postmodernism, "after" Hayden White, or "post"-narrativism. ${ }^{2}$ Like everyone else, philosophers of history have, of course, good reasons for doing so. Apart from that "paradigm changes" and "ground breaking" innovation have become highly valued goods, philosophy of history is a different field nowadays than it was in the 1950s or in the 1980s. A theme issue on "Historical Thinking and the Human," published last year by this journal, would have been unthinkable half or even a quarter of a century ago. And isn't it always more rewarding for curious academics to explore untrodden paths than to return to the work of others? If only for these reasons, it is not surprising that philosophers of history are said to be attentive to "the current situation in history and theory," while "looking for new organizing principles."3

Yet the more firmly philosophers of history anchor themselves in the present (however broadly or narrowly defined), the more marked becomes their distance from the past - not only from Georg Simmel's Die Probleme der Geschichtsphilosophie (1892, 2nd ed. 1905/1907) or Raymond Aron's Introduction à la philosophie de l'histoire (1938), but also from Hayden White's Metahistory (1973) and Jörn Rüsen's Grundzüge einer Historik (3 vols., 1983-1989). In their calls to move "beyond hermeneutics," to "transcend our narrativist past," or to develop a philosophy of history "after Hayden White," philosophers of history display a posterizing impulse not unlike the one that Taylor observed in African American studies. We are told that if philosophers of history are to have "relevance in the contemporary world," they should adopt a "post-postmodern" stance, move beyond "humanism" and "anthropocentrism," or exorcise the demon of empiricism lurking in "praxeology." Regardless of how one values these proposals, it is clear that their emphasis on the intellectual needs of the present has the effect, intentionally or not, of relegating most of what precedes the "now" to a past that is supposedly over and done with.

This is remarkable, for two reasons. Philosophers of history, after all, know everything about stadial thinking, "denial of coevalness," and "the politics of

2 Paul C. Taylor, "Post-Black, Old Black," African American Review 41, no. 4 (2007), 625-640, at 626 .

3 Gabrielle M. Spiegel, "The Future of the Past: History, Memory and the Ethical Imperatives of Writing History," Journal of the Philosophy of History 8, no. 2 (2014), 149-179, at 155; JouniMatti Kuukkanen, "A Conceptual Map for Twenty-First-Century Philosophy of History," in Philosophy of History: Twenty-First-Century Perspectives, ed. Jouni-Matti Kuukkanen (London: Bloomsbury, 2021), 1-19, at 4. 
periodization." More than anyone else, they know that "the present" is a multiverse concept and that, consequently, value-laden demarcations between past and present often reveal more about the boundary-drawers and their Sitz im Leben than about the past in question. So how is it that philosophers of history, experts in challenging all-too-easy narratives of historical succession, see no harm in letting the history of their own discipline disappear into the past? Secondly, even if White's existentialism and Marrou's Catholicism may have an antiquated ring to them, how "past" really are the questions that these authors sought to address? One does not need to subscribe to an ahistorical and therefore untenable notion of "timeless philosophical issues" to recognize that, for example, White's worries about the disciplining effects of professional history writing are as relevant in neoliberal academia as they were in the 196os, a time when "method" and "objectivity" instead of "output" and "outreach" still served as standards for performance. Likewise, Wilhelm Dilthey's inquiries into the epistemology of the human sciences, though conducted in the 188os in a vocabulary with which few academics are still familiar, speak almost directly to present-day concerns, judging by how humanities scholars are struggling to make themselves heard in STEM-dominated environments. Even "speculative" philosophy of history, almost flogged to death in the mid-twentieth century, seems on the verge of a second (third? fourth?) life in an age that is facing increasingly grim futures. ${ }^{4}$

So what can philosophers of history do to develop more constructive relations with the history of their own field? Following White's "turning of the Ironic consciousness against Irony itself," ${ }^{n}$ they might issue yet another manifesto for change, emphasizing the need to move "beyond" a merciless logic of temporal succession (which some would argue is fueled by a capitalist temporality of acceleration). Inspired by anthropologists who have become increasingly skeptical of their own habit of dividing the world into "old" and "new," they might inquire into what it takes to "[wean] ourselves from the traditional conceit of breaking with the past." ${ }^{\prime 6}$ Post-historicism might be an appropriate label for this post-movement, as long as we understand historicism to denote a type of stadial thinking that divides historical "development" into a series of

4 See, e.g., Frank Ankersmit, "The Thorn of History: Unintended Consequences and Speculative Philosophy of History," History and Theory 6o, no. 2 (2021), 187-214.

5 Hayden White, Metahistory: The Historical Imagination in Nineteenth-Century Europe (Baltimore, MD: Johns Hopkins University Press, 1973), xii.

6 Peter Pels, "Modern Times: Seven Steps towards an Anthropology of the Future," Current Anthropology 56, no. 6 (2015), 779-796, at 789 . 
successive "epochs." ${ }^{7}$ Yet the limitations of this strategy are obvious: its advocates are complicit in the very same dynamics that they seek to challenge.

This theme issue therefore takes another approach: it draws attention to nine half-forgotten philosophy of history books from the past century and a half, with the aim of encouraging new readings and fresh assessments of how these books, in spite of being "old" and supposedly "superseded," still speak, in sometimes surprising ways, to twenty-first-century concerns. Concretely, we have invited nine philosophers of history to pick a title of their own choosing and contribute an essay that addresses two questions:

1. What did this book originally try to do? What were the author's ambitions, concerns, or guiding questions?

2. How does the book speak to twenty-first-century audiences, for instance in how it aligns with or, alternatively, exposes the limits of current-day trends in the philosophy of history?

Methodologically, we have granted the authors full freedom, without imposing on them our own views on what constitutes a meaningful dialogue across time. ${ }^{8}$ Consequently, the essays vary in how they proceed. While some articles engage in detailed historical reconstruction to rescue the study of their choosing "from the enormous condescension of posterity," others draw on allegorical or anagogical modes of exegesis to make old texts say new things in new contexts. What the essays have in common, though, is a healthy dissatisfaction with a supersessionary mode of thinking - Taylor's posterizing impulse - that excludes books like Benedetto Croce's La storia come pensiero e come azione (1938), Jerzi Topolski's Metodologia historii (1968), and Peter Munz's The Shapes of Time (1977) from present consideration. Each in their own way, the essays address an issue perceptively raised by Berber Bevernage et alia in an article about the future of philosophy of history: "Thinking the question of the future involves thinking the question of how to critically inherit: how, for example, can we deal with older research questions without being paralyzed by them? Do we have the legitimacy to posit radically new questions and, if necessary,

7 On the persistence of historicist thinking so defined in twentieth-century "post" discourses, see Herman Paul, "Introduction: Post-Concepts in Historical Perspective," in Post-Everything: An Intellectual History of Post-Concepts, ed. Herman Paul and Adriaan van Veldhuizen (Manchester: Manchester University Press, 2021), 1-14. Elsewhere in this same volume, Yolande Jansen, Jasmijn Leeuwenkamp, and Leire Urricelqui ("Posthumanism and the 'Posterizing Impulse," ibid., 215-233) also draw on Taylor's concept of "posterizing."

8 See, e.g., Herman Paul, "What Could It Mean for Historians to Maintain a Dialogue With the Past?" Journal of the Philosophy of History 8, no. 3 (2014), 445-463. 
put the old ones aside? When, if ever, can we declare an intellectual alley to be a dead end?"9

This theme issue can therefore be read as an invitation to reconsider, reappropriate, and, above all, reread once-famous books like Leo Tolstoy's War and Peace (1864), Thomas Kuhn's The Structure of Scientific Revolutions (1962), and Herbert Marcuse's One-Dimensional Man (1964). It encourages readers to dust off half-forgotten books like Paul Lacombe's De l'histoire considerée comme science (1894), to take a fresh look at David Harlan's often criticized The Degradation of American History (1997), and to allow themselves to be surprised by Heinz-Dieter Kittsteiner's Out of Control: Über die Unverfügbarkeit des historischen Prozesses (2004). Even if, as Walter Benjamin argued, the forces of our time propel us forward, "post" and "beyond" even the most avantgarde currents of thought, philosophers of history know, or should know, how to look backwards, realizing that the past is never dead: "It's not even past."10

9 Berber Bevernage et al., "Introduction: The Future of the Theory and Philosophy of History," Journal of the Philosophy of History 8, no. 2 (2014), 141-148, at 146.

10 William Faulkner, Requiem for a Nun (New York: Random House, 1951), 92. 